\title{
HIV/AIDS knowledge in detention in Hunan province, China
}

\author{
Weidong Zhang ${ }^{\dagger 1}$, Xinya Wang ${ }^{\dagger 2}, X_{i}$ Chen $^{3}$ and Fan Lv²
}

\begin{abstract}
Background: Injection drug use (IDU) is one of the major modes of HIV transmission in China. Drug use is illegal in China, all identified drug users are registered by Public Security Bureau, and most were sent to detention; most detainees engaged in high risk behaviours. In order to well understand the HIV/AIDS knowledge among detainees, a survey was conducted in different detention settings in Hunan province in 2008 to assess knowledge and attitudes about HIV among detainees and to provide useful information for HIV prevention and intervention strategies in detention centers.

Methods: A cross-sectional survey was conducted in 10 detentions in Hunan province, China, and demographic information along with knowledge and attitude of HIV/AIDS was collected through standardized interviews. Descriptive statistics were used to describe HIV knowledge, attitudes, and education services among detainees.

Results: There were 956 detainees interviewed from 10 detention centers. The male to female ratio was 2.24:1. The majority detainees received nine years of compulsory education, accounting for $51.5 \%$. There were nine questions to assess HIV/AIDS knowledge of detainees, and $35.7 \%$ of those surveyed answered all nine questions correctly. There were $92.3 \%$ (882/956) who consented to be informed about the HIV antibody test results when tested, and 81\% (774/ 956) elected that their family members were also informed. All detention centers had an organized HIV/AIDS education program.
\end{abstract}

Conclusion: This study gives us an overview about HIV/AIDS knowledge in detention in Hunan province, and all detention sites in the study provided HIV/AIDS intervention services among detainees that focused on HIV/AIDS knowledge, attitude, and health behaviors.

\section{Background}

Injection drug use (IDU) is one of the major modes of HIV transmission in China [1]. Drug use is illegal in China, and all identified drug users are registered by China's Public Security Bureau. By the end of 2004, there were cumulative 1.14 million registered drug users in China [2]. Through 2004, injection drug users (IDUs) accounted for about $70 \%$ of total cumulative reported HIV infections in China [3]. By the end of 2007, there were approximately 700,000 people currently living with HIV/AIDS in China, including approximately 266,700 drug users. This accounts for $38.1 \%$ of the total number of estimated HIV cases. It is estimated that there were

\footnotetext{
* Correspondence: fanlv@vip.sina.com

2 National Center for AIDS/STD Control and Prevention, Chinese Center for

Disease Control and Prevention, Beijing, PR China

+ Contributed equally

Full list of author information is available at the end of the article
}

50,000 new HIV infections in 2007. Of the new infections, heterosexual transmission accounts for an estimated 44.7 percent of cases and injection drug use is estimated to account for 42 percent of transmission. Sexual transmission is now the primary risk factor for HIV transmission[4].

The Chinese government has issued a series of laws and regulations to response to the HIV/AIDS epidemics and injection drug use. Prevention and intervention campaigns have addressed drug dependency and HIV, such as greatly expanding methadone maintenance therapy (MMT) and clean needle exchange programs. By the end of October 2007, 397 MMT clinics were open in 22 provinces, autonomous regions, and municipalities with 88,313 participants in the MMT treatment program. In 2006, a total of 729 needle exchange stations were established in 204 counties or districts in 17 provinces. By the third quarter of 2007, about 49,108 IDUs had participated 
in clean needle exchange programs [4]. Registered drug users were also sent to detention, such as detoxification and labour re-education centers in order to participate in a compulsory detoxification program [5-8].

While in detention centers, most detainees engaged in high risk behaviours, and some special characteristics of detention centers contribute to HIV transmission, such as crowded space, almost all the same gender, fighting, and other factors [9-16]. Therefore, the HIV/AIDS risk in detention is high. For the public security staff, there is also occupational HIV exposure. The same situation also existed in Chinese detention centers, especially for obligatory detoxification centers, labor detoxification centers, and female re-education centers. According to some studies, the HIV positive seroprevalence rate was between $5-10 \%$ in sentinel detention centers [17-19].

In order to better understand the trends of HIV epidemic and knowledge, attitudes and practices (KAP) about HIV among high-risk population groups, China created an HIV sentinel surveillance system in 1995, focusing efforts on groups including drug users, female sex workers, sexual transmitted diseases (STD) clinic clients, Men who have sex with men (MSM), male long distance truck drivers and students [20]. Sentinel sites for drug users and female sex workers also include obligatory detoxification centers, labor detoxification centers, and female re-education centers.

The aim of our study is to describe the results of survey among detainees in Hunan province in China conducted in 2008, to assess HIV knowledge and practices among detainees, and to provide useful information for HIV prevention and intervention strategies in detention centers.

\section{Methods}

\section{Study sample}

This investigation involved the public security and justice system. Specifically, the public security system included obligatory detoxification centers and custody houses, and the justice system included labor re-education centers and prison.

Detention centers were selected using stratifying sampling method, detoxification centers and custody houses were selected in the public security system, and prison and re-education centers were selected in the justice system. A Multi-level random sampling method was used to recruit individuals in different detention centers. Ten centers were randomly selected according to the system, and then at least 110 individuals were selected in every single detention center. A self-reported questionnaire was used to collect needed information.

The survey was conducted from 13 October to 30 October, 2008. Anonymity and confidentiality were guaranteed to the detainees when they participated in the sur- vey. Under the approval of the protocol "HIV Surveillance Protocol" by the national ethical committee of China (Institutional Review Board), informed consent from participants in behavioral surveillance was required during survey [21].

Different types of detention canters were selected in order to gain better representativeness, such as centers only for women, obligatory detoxification centers, custody houses, labor re-education centers, and prison. Variables used in this study included sample source, gender, age, marital status, resident place, ethnic groups, education background, profession, time of entry detention, time space of detention, cause of detention, AIDS information, intervention and prevention services, and others.

\section{HIV/AIDS response in detention}

All detention centers had an organized HIV/AIDS education program. Activities included seminars, workshops, and training for security staff; non-profit activities; some volunteer and some students gave courses or health education, such as "No Drug", "Health Behavior", and others. Video courses and notice boards, as well as posters, were also used for promotion of HIV/AIDS knowledge. In some detention centers, peer education and counseling were also used.

Most detention centers attempt to implement comprehensive HIV management. In one labor re-education center, Xinkaipu, a "caring center" for HIV positives started in July 2008; Baimalong established "HIV prevention unit" in July 2008. In prison, no HIV positive individuals were identified, and in a female prison, few HIV positive individuals were identified, and an established isolation caring center was implemented to provide case management collectively.

\section{Data analysis}

The sample size included 979 samples from 10 detention centers. Epidata was used for data entry and database management. First, data cleaning was conducted, in which 23 samples were deleted. After data cleaning, a total of 956 records were included in the analysis. SPSS software (version 14.0 for Windows; SPSS Inc., Chicago, IL) was used to analyze the dataset.

\section{Results}

\section{Characteristics of the study sample}

There were 660 male, and 296 female, so the male to female ratio was 2.24:1. Local Hunan residents were 920, accounting for $94.4 \%$ of the sample size; transient detainees from other provinces without local permanent residence permission were 52 , which accounted for $5.4 \%$. The participants were predominantly Han Chinese, which accounted for $96.9 \%, 3.1 \%$ were minority ethnic groups. 
47.7\% samples were single, $30.6 \%$ samples married, and the remaining people were cohabiting, divorced or widowed.

The major part of detainees received nine years of compulsory education, accounting for $51.5 \%$ of the total sample size. Those with primary school or high school education were $20.0 \%$ and $21.4 \%$, respectively. The illiteracy was $2.0 \%$. See Table 1 . Of the total, $30.2 \%$ of detainees were jobless; while job categories of the employed included farmer (24.9\%), blue collar worker (12.3\%), and commercial service staff (10.4\%).

Illegal drug use was the cause of detention for $47 \%$ (449/956) of the study participants; commercial sex or other reasons accounted for $51.5 \%(492 / 956)$.

\section{HIV/AIDS knowledge}

There were nine questions to assess the HIV/AIDS knowledge of detainees, $35.7 \%$ of the participants answered all 9 questions correctly. The lowest correct answer rate of the nine questions was "does mosquito bite can transmit HIV virus?" (63.1\% answered correctly). See Table 2. There were $1.2 \%$ of participants who had never heard HIV/AIDS.

\section{HIV/AIDS intervention services}

There were $67.4 \%(644 / 956)$ of study participants who received HIV/AIDS information materials. The propor- tion of participants who received condom distribution and Voluntary Counseling and Testing (VCT) was $31.2 \%$ (298/956) and 49\% (468/956), respectively.

\section{HIV test}

There were 204 participants who had been tested for the HIV antibody before being sent to detention, which accounted for $21.3 \%$ (204/952). Of these 79.4\% (162/204) knew the test results, and 36 samples were aware of HIV positive results. Most of the HIV antibody tests were conducted in a Center for Disease Control (CDC) or in other detention centers.

The total number of participants tested for HIV antibodies inside detention was 580, which accounted for $60.7 \%(580 / 951)$. Of these, $41.4 \%(240 / 580)$ participants were drug users; and $29.8 \%(173 / 580)$ samples knew the results. Of the $47 \mathrm{HIV}$ positive participants, 36 were drug users. There were no HIV positive individuals identified among commercial sex workers.

\section{Test Result Notification}

There were $92.3 \%$ (882/956) who wished to be notified about the test results if tested, and 81\% (774/956) indicated that they wished that their family members were also notified. Of those participating in the survey, $23.4 \%$ (224/956) indicated that they would like to live with HIV positive individuals, while $55.1 \%$ (527/956) indicated that

Table 1: Characteristics of sample from detentions $(\mathrm{N}=\mathbf{9 5 6})$.

\begin{tabular}{|c|c|c|c|}
\hline item & & number & percent (\%) \\
\hline \multirow[t]{2}{*}{ Gender } & male & 660 & 69.1 \\
\hline & female & 296 & 30.9 \\
\hline \multirow[t]{4}{*}{ Marital status } & single & 453 & 47.4 \\
\hline & married & 293 & 30.7 \\
\hline & cohabited & 53 & 5.3 \\
\hline & divorced & 157 & 16.5 \\
\hline \multirow[t]{5}{*}{ Age } & $\leq 18$ & 43 & 4.5 \\
\hline & $19-30$ & 377 & 39.5 \\
\hline & $31-40$ & 394 & 41.2 \\
\hline & $41-50$ & 119 & 12.5 \\
\hline & $>50$ & 23 & 2.4 \\
\hline \multirow[t]{5}{*}{ Education } & Illiteracy & 19 & 2.0 \\
\hline & Primary school & 192 & 20.0 \\
\hline & Middle school & 492 & 51.5 \\
\hline & High school & 205 & 21.4 \\
\hline & College or above & 48 & 5.0 \\
\hline \multirow[t]{3}{*}{ Reason for detention } & Drug use & 449 & 47.0 \\
\hline & Commercial sex & 16 & 1.5 \\
\hline & Others & 491 & 51.4 \\
\hline
\end{tabular}


Table 2: HIV/AIDS knowledge of detainees $(\mathrm{N}=956)$.

\begin{tabular}{lcc}
\hline Subject & Correct answers & Correct rate (\%) \\
\hline Ever heard of HIV/AIDS & 945 & 98.8 \\
Can a person carry HIV while still appearing healthy & 781 & 81.7 \\
Can HIV infected blood or blood product transmit HIV virus & 900 & 94.1 \\
Can sharing needles with HIV positive person transmit HIV virus & 908 & 95.0 \\
Can using condom correctly reduce the risk of transmission of HIV virus & 682 & 71.3 \\
Can an HIV infected pregnant woman transmit HIV virus to her baby & 867 & 90.7 \\
Can eating with an HIV infected person transmit HIV virus & 779 & 81.5 \\
Can a mosquito bite transmit HIV virus & 603 & 63.1 \\
Are people lawfully responsible if he/she transmits HIV virus intentionally & 765 & 80.0 \\
\hline Total answering all nine questions correctly & & $\mathbf{3 5 . 7}$ \\
\hline
\end{tabular}

they did not like living with HIV positive individuals. There were $89 \%$ (851/956) of participants who wanted to be informed directly after the test. See Table 3.

\section{Risk behaviors}

Of those interviewed in re-education centers and detoxification centers, all participants have drug use history; however, in custody houses and prisons, only a few people have a drug use history. Most drug users once shared needles, but most reported that this typically occurred at the beginning of drug use. After receiving HIV/AIDS information, needle sharing behavior almost stopped completely. Needles were typically bought in drug stores by individuals, not in clean needle exchange centers, because most clean needle exchange centers are far, and it is possible to be arrested by police. Individuals in higher social economic status (SES) levels reported using drugs at home, and did not report Needle sharing practices.

Most male detainees reported commercial sex use, and also reported sexual activity with heterosexual drug partners. Most detainees used condoms with commercial sex workers, but did not use condoms with established sex partners.

\section{Discussion}

This study gives us an overview about HIV/AIDS knowledge in detention in Hunan province, China, but information about the HIV/AIDS risk behavior among detainees was still limited. Random sampling methods is very difficult or nearly impossible. Because of the characteristics of this population group and the operational difficulties of such investigation, legal and ethical issues should be considered [9,12-15]. Psychological factors are often neglected in China, and mental health factors should also be considered. Our finding demonstrates that the need and urgency of HIV/AIDS education campaigns in detention centers; and, our data provides an important reference for researchers and public health policy makers.

All detention sites in our study provided HIV/AIDS intervention services among detainees, and it improved HIV/AIDS knowledge, attitudes, and health behaviors among detainees. However, intervention should take

Table 3: Samples' attitude of being informed of HIV test results.

\begin{tabular}{|c|c|c|c|c|c|c|c|c|}
\hline \multirow[b]{2}{*}{ Attitude } & \multirow{2}{*}{$\begin{array}{c}\text { Wish to be } \\
\text { informed of } \\
\text { test results } \\
\text { Yes }\end{array}$} & \multirow{2}{*}{$\begin{array}{c}\text { Wish to have } \\
\text { test results } \\
\text { delivered to } \\
\text { family member }\end{array}$} & \multicolumn{3}{|c|}{ Living with HIV positives } & \multicolumn{2}{|c|}{ Time to be informed } & \multirow[t]{2}{*}{ Total } \\
\hline & & & Like & Not like & $\begin{array}{c}\text { Doesnot } \\
\text { matter }\end{array}$ & $\begin{array}{l}\text { Directly } \\
\text { after test }\end{array}$ & $\begin{array}{c}\text { Later in } \\
\text { other time }\end{array}$ & \\
\hline Number & 882 & 774 & 224 & 528 & 204 & 851 & 105 & 956 \\
\hline $\begin{array}{l}\text { Percent } \\
\text { (\%) }\end{array}$ & 92.3 & 81.0 & 23.4 & 55.1 & 21.3 & 89.0 & 11.0 & 100 \\
\hline
\end{tabular}


action as early as possible in order to be effective and prevent further transmission [22,23]. Providing HIV/AIDS prevention and intervention services in detention centers could reduce the HIV/AIDS transmission among general population, because most detainees return to their communities after leaving detention centers. Many are at high risk for HIV/AIDS, such as drug use, commercial sex, and other factors. For HIV test result notification in detention centers, considerations should be discussed about the problematic and legal issues involved. However, test results should be provided as soon as possible, since most HIV positive individuals indicated that they would cooperate with intervention and treatment. Evidence has shown that there is a positive change in detainees' attitudes to safe sex, harm reduction, and health behaviors $[23,24]$. Such problems are not only public health problems, but they also need political and legal support.

Since the emergence of the HIV epidemic, China has launched an HIV prevention and harm reduction program. A comprehensive program to prevent the further transmission of HIV among drug users has been implemented that includes community based harm reduction programs, primarily a methadone maintenance treatment and needle-syringe program. In 2003, China announced a national AIDS control policy, "Four Frees and One Care" (free treatment, free Voluntary Counseling and Testing (VCT), free Prevention of Mother to Child Transmission (PMCT) and free education for AIDS orphans, and provision of social relief and care for HIV patients) [25].

\section{Conclusion}

This study gives us an overview about HIV/AIDS knowledge in detention in Hunan province, and all detention sites in the study provided HIV/AIDS intervention services among detainees that focused on HIV/AIDS knowledge, attitude, and health behaviors. These efforts are likely to require an infrastructure that not only provides operational and financial support, but also creates an environment in which at-risk populations feel comfortable and safe in seeking help and non-discrimination.

\section{Competing interests}

The authors declare that they have no competing interests.

\section{Authors' contributions}

XW, WZ, XC and FL designed and conducted the analysis, WZ conducted the analysis and wrote the final version of the text. XC, FL and XW developed the questionnaire; XW collected the raw data on sites. All authors read and approved the final manuscript.

\section{Acknowledgements}

We thank Prof. Alexander Kraemer and Dr. Marc Bulterys for valuable advice, we thank Mr. Patrick Flaherty for the language editing and valuable comments for this paper; we also thank Dr. Sten Vermund and Dr. Yujiang Jia for review this paper.

\section{Author Details}

1 Office for Disease Control and Emergency Response, Chinese Center for Disease Control and Prevention, Beijing, PR China, ${ }^{2}$ National Center for AIDS/ STD Control and Prevention, Chinese Center for Disease Control and Prevention, Beijing, PR China and ${ }^{3}$ Hunan provincial Center for Disease Control and Prevention, Changsha, PR China

Received: 26 May 2009 Accepted: 28 April 2010

Published: 28 April 2010

References

1. China CDC. Chinese National Center for Disease Control and Prevention: Annual report of national AIDS/STD surveillance in 2002: analysis of HIV epidemic in 2002. Beijing: Chinese National Center for Disease Control and Prevention; [Chin]; 2003:6-9.

2. Liu Z, Lian Z, Zhao C: Asia pacific column - Drug use and HIV/AIDS in China. Drug and alcohol review 2006, 25:173-175.

3. China CDC:HIV/AIDS comprehensive surveillance annual report. [Chin] 2005.

4. WHO/MOH/UNAIDS: A joint assessment of HIV/AIDS prevention, treatment and care in China. 2007.

5. Sullivan SG, Wu Z: Rapid scale up of harm reduction in China. Int J Drug Policy 2007, 18:118-128.

6. 5. State Council of the People's Republic of China: Chinese National medium-and long-term strategic plan for HIV/AIDS prevention and control (1998-2010). In State Council Document GF Beijing: State Council. [Chin]; 1998

7. State Council of the People's Republic of China: China's action plan for reducing and preventing the spread of HIV/AIDS (2001-2005). In State Council Document 2001 Beijing: State Council. [Chin].

8. State Council of the People's Republic of China: State council notice on strengthening HIV/AIDS prevention and control. In State Council Document 2004(7) Beijing: State Council. [Chin].

9. Cohen JE, Amon JJ: Health and human rights concerns of drug users in detention in Guangxi Province, China. PLoS Med 2008, 5(12):e234

10. Springer SA, Bruce RD: A pilot survey of attitudes and knowledge about opioid substitution therapy for HIV-infected prisoners. J Opioid Manag 2008, 4(2):81-6

11. Sarang A, Rhodes T, Platt L, Kirzhanova V, Shelkovnikova O, Volnov V, Blagovo D, Rylkov A: Drug injecting and syringe use in the HIV risk environment of Russian penitentiary institutions: Qualitative study. Addiction 2006, 101(12):1787-96.

12. Teplin LA, Mericle AA, McClelland GM, Abram KM: HIV and AIDS risk behaviors in juvenile detainees: implications for public health policy. Am J Public Health 2003, 93(6):906-12

13. Bollini $P$, Laporte JD, Harding TW: HIV prevention in prisons. Do international guidelines matter? Eur J Public Health 2002, 12(2):83-9.

14. Braithwaite RL, Arriola KR: Male prisoners and HIV prevention: a call for action ignored. Am J Public Health 2003, 93(5):759-63.

15. McClelland GM, Teplin LA, Abram KM, Jacobs N: HIV and AIDS risk behaviors among female jail detainees: implications for public health policy. Am J Public Health 2002, 92(5):818-25.

16. Drobniewski FA, Balabanova YM, Ruddy MC, Graham C, Kuznetzov SI, Gusarova GI, Zakharova SM, Melentyev AS, Fedorin IM: Tuberculosis, HIV seroprevalence and intravenous drug abuse in prisoners. Eur Respir $J$ 2005, 26(2):298-304

17. Zhang L, Yao G, Ruan F: Survey of HIV prevention among prisoners in Zhuhai. Practical Preventive Medicine. [Chin] 2007, 4(14):1700-1701.

18. Zheng Z, Meng Q: Medical service needs in detention centers. Chinese health economics. [Chin] 2008, 3(27):41-42.

19. Xiu C, Jiang Z, Chu Q, Wang Z, Fa P, Hao H: KAP about AIDS among prisoners and relevant intervention. Chinese journal of health education. [Chin] 2004, 11(20):1002-3.

20. China CDC: Guideline of national HIV/AIDS comprehensive surveillance. [Chin]. 2005

21. Sun X, Wang N, Li D, Zheng X, Qu S, Wang L, Lu F, Poundstone K, Wang L: The development of HIV/AIDS surveillance in China. AIDS 2007, 21(Suppl 8):S33-38.

22. UNODC: HIV and AIDS prevention care treatment and support in prison settings: A framework for an effective national response. Vienna 2006. 
23. Bauserman RL, Richardson D, Ward M, Shea M, Bowlin C, Tomoyasu N, Solomon L: HIV prevention with jail and prison inmates: Maryland's Prevention Case Management program. AIDS Educ Prev 2003, 15(5):465-80.

24. Zhuang M, Kang L, Bao J, Ning Z, Zhang G, Chen A, Pan Q: HIV positives management model in detention. Chin J STD/AIDS Prev Cont. [Chin] 2001, 4(8):239-40

25. Wu Z, Sullivan SG, Wang Y, Rotheram-Borus MJ, Detels R: Evolution of China's response to HIV/AIDS. Lancet 2007, 369(9562):679-90.

Pre-publication history

The pre-publication history for this paper can be accessed here: http://www.biomedcentral.com/1471-2458/10/221/prepub

doi: $10.1186 / 1471-2458-10-221$

Cite this article as: Zhang et al., HIV/AIDS knowledge in detention in Hunan province, China BMC Public Health 2010, 10:221

Submit your next manuscript to BioMed Central and take full advantage of:

- Convenient online submission

- Thorough peer review

- No space constraints or color figure charges

- Immediate publication on acceptance

- Inclusion in PubMed, CAS, Scopus and Google Scholar

- Research which is freely available for redistribution

Submit your manuscript at www.biomedcentral.com/submit
() BioMed Central 